\title{
Metastable States and Physical Properties of Boron-rich W-B films
}

\author{
V.F. Bashev*, S.I. Ryabtsev, T.V. Kruzina, S.A. Popov, E.S. Skorbyaschensky, \\ Yu.N. Potapovich, S.N. Antropov ${ }^{\dagger}$ \\ Department of Experimental Physics, Oles Honchar Dnipro National University, 72, Gagarin Ave., \\ 49010 Dnipro, Ukraine
}

(Received 29 July 2020; revised manuscript received 18 December 2020; published online 25 December 2020)

\begin{abstract}
The experimental data on the ion-plasma (13.56 MHz) magnetron sputtering of composite targets of the system W-B are presented. Application of this method allows one to obtain deposited alloys in the entire concentration range of compositions. The as-deposited films show the formation of an amorphous solid state. The decomposition of an amorphous state is accompanied by precipitation of an intermediate metastable, nanocrystalline W-phase with FCC-structure. By applying magnetron sputtering, we have obtained an amorphous state in pure $\mathrm{W}$-films at room temperature. The thermal stability, electrical and mechanical properties of metastable states in W-B films are studied. The study shows that the amorphous state in the $\mathrm{WB}_{5}$ alloy is characterized by abnormally high temperature stability and microhardness. The ion-plasma sputtering method has demonstrated its effectiveness in the case of tungsten films, showing the possibility of obtaining metastable phases in them. At the same time, the obtained values of microhardness in the amorphous alloy turned out to be lower than the predicted maximum theoretical values due to the peculiarities of the location of atoms in the alloy.
\end{abstract}

Keywords: Ion-plasma magnetron sputtering, Amorphous state, Metastable states, W-B films, Temperature stability, Microhardness.

DOI: $10.21272 /$ jnep.12(6).06016

PACS numbers: 81.15.Cd, 81.40.Cd, 64.60.My

\section{INTRODUCTION}

The boride phases in structural and tool steels are carefully studied in the course of industrialization based on the needs not only of the nuclear branch, but also in view of practical needs of metallurgical, engineering and defense industries. The unique properties of boron, so, have been of practical interest for more than half a century [1]: methods for creating surface layers with borides to a depth of only a dozen microns, while reducing the cost of processing parts by 3-5 times compared to the known ones has increased the wear resistance of parts by 10-15 times even for simple steels without scarce alloys. Coating of the experimental boride phases (see Refs. in [1]) has shown unique characteristics not only of the Fe-B-C system, but also of other ones: to describe the desired properties of the materials being developed, the boride phases technologies have been worked out with elements $\mathrm{Cu}, \mathrm{Al}$ (Refs. in [2]), Ti [2], which seems to have led the authors to describe new phases at the atomic level [3], to simulate crystallization by the molecular dynamics method [4], to form structures at mass crystallization of amorphous alloys, to study multicomponent high-entropy alloys (Refs. in [5]), the special and rapid modes quenching from liquid and vapor states [6], as well as modeling of metastable phases (Refs. in [5]), in particular, by modernized methods of ion-plasma sputtering [5].

\section{OBJECTS DESCRIPTION}

\subsection{Stable Tungsten Boride Phases}

New hard materials are important for modern industry. These materials must have Vickers hardness higher than $40 \mathrm{GPa}$. The well-known hard materials are carbon allotropy (diamond), carbon nitrides, borides, nitrides, and carbides of transition metals. The carbides (WC) and nitrides (TiN) are widely used in machining tools and mining, e.g., in drilling equipment. There are some following stable tungsten boride phases known from experiments in $\mathrm{W}-\mathrm{B}$ system: $\mathrm{W}_{2} \mathrm{~B}, \mathrm{WB}(a$ and $\beta$ phases), $\mathrm{WB}_{2}, \mathrm{~W}_{2} \mathrm{~B}_{5}$, and $\mathrm{WB}_{4}$, synthesized by arc melting [7, 8] (see tungsten boride phases known from experiments with W-B system in 1990th, as well as the binary alloy phase diagrams of Refs. in [5]).

\subsection{Predicted Phases}

Significant funds are used to establish a relationship between the structural elements of materials and their properties. However, in the materials science such a study has been carried out quite detailed with respect to elements B and W considered independently [9].

At the same time, "the less expensive" theoretical methods for studying crystalline structures [10] have also confirmed the complexity of modeling systems with boron [11], faced with the limited resources with an "expected cost of discovery" [12], allowing one to describe tungsten borides, but with limitations [13].

New genetic algorithms, evolutionary ones, and their upturn by USPEX [14] allow to detect new phases by parallel computing and saving computational resources if appropriate experimental results are accumulated, which would help clarify the modelling.

The results of theoretical studies have identified just tungsten borides as possible candidates for superhard materials $[15,16]$. Calculations indicating a certain adaptive structure of borides [17] also have re-

\footnotetext{
*bashev_vf@ukr.net

† santdnu1@gmail.com
} 
vealed a lack of experimental data and increasing controversy in the literature.

The likely scarcity of funding for relevant research projects, however, reveals especially sharply the lack of practical techniques for creating new phases, the computational efforts to describe which have recently been so little noticed $[18,19]$.

In [18], it is predicted the boron-rich phase WB5 with anomalously high hardness and high fracture toughness. The absence of $\mathrm{WB}_{5}$ phase on the phase diagrams of 1990th and [8] may be naturally explained by the difficulties on the path of its formation as the peritectoid $\left(\mathrm{WB}_{4}+\mathrm{B}=\mathrm{WB}_{5}\right)$ type. However, by the method of ion-plasma sputtering, the formation of this phase directly from the vapor state is possible under the conditions of reaching necessary undercooling and realization of the metastable equilibrium between phases $\mathrm{WB}_{4}, \mathrm{~B}, \mathrm{WB}_{5}$. The possibility of this mechanism is discussed at quenching from the liquid state in 1982 (see Ref. in [5]). In [18], by computed method it is investigated the boron-rich side of $\mathrm{W}$-B system, in particular, the compound $\mathrm{WB}_{5}$, which remains a highperformance material. This compound may possess the ultrahigh mechanical hardness of $45 \mathrm{GPa}$. The predicted boride $\mathrm{WB}_{5}$ has a structure consisting of hexagonal prisms $\mathrm{WB}_{12}$, in which the $\mathrm{W}$ atom is coordinated by $12 \mathrm{~B}$ atoms, and the open $\mathrm{B}_{15}$ clusters are linked by $\mathrm{B}-$ $\mathrm{B}$ bonds into a 3D-structure (Fig. 1) [18].

\section{Pmmn-WBs}

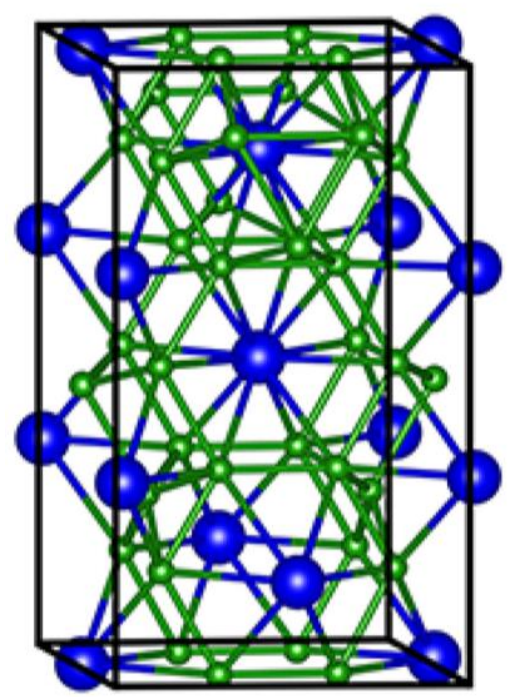

Fig. 1 - Crystal structure of the predicted $P_{m m n W B}$ phase [18], smaller balls correspond to boron atoms, larger ones - to tungsten atoms

The Ashby plot of Vickers hardness represents some mechanical properties of phases in the W-B system, from which it follows that the predicted phase $\mathrm{WB}_{5}$ may have ultrahigh mechanical properties [18].

\section{EXPERIMENTAL}

Solubility of B in $\mathrm{W}$ is practically absent. It is of interest to establish the ability of WB5-phase to form metastable (including amorphous) states under nonequilibrium conditions of crystallization, in particular, in the process of vapor deposition. In order to obtain this phase we use the method of ion-plasma sputtering in vacuum. The films of this system are obtained by $R F$ magnetron sputtering technique $(13.56 \mathrm{MHz})$ using a composite target. The generated torus-shaped plasma affects the target sputtering process and results in the formation on its surface of erosion in the form of a ring with diffuse edges (1, 2 in Fig. 2 ) that is typical of the magnetron sputtering method. Usually for installation in a magnetron, a single-component target is prepared as a disk with larger diameter than the plasma torus diameter. The multicomponent target is prepared as a disk consisting of triangular sectors. Each sector is an individual component of the target (Fig. 2).

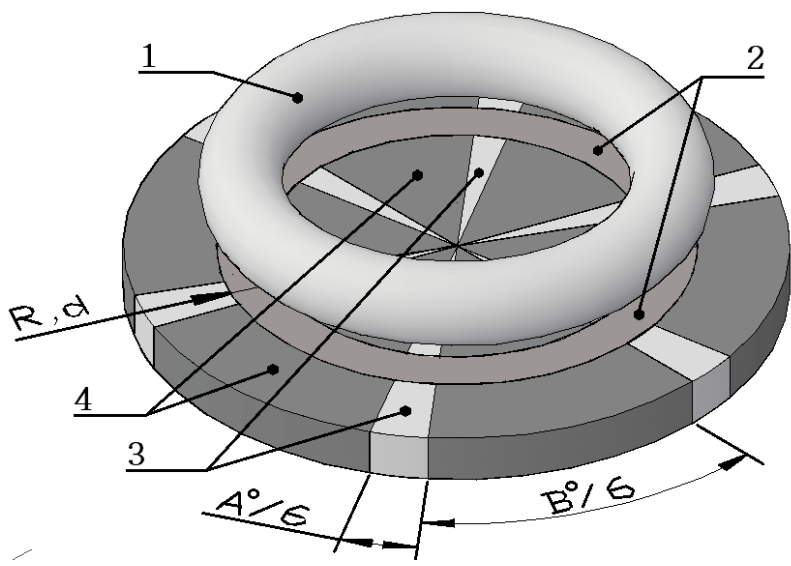

Fig. 2 - The composite target under plasma effect: 1 - torusshaped plasma, $2-$ zone of target erosion $(R$ and $d$ are radius and thickness of the erosion ring), 3 - sectors of A components, 4 - sectors of $\mathrm{B}$ components

For the production of the films of most stoichiometric composition, the sectors were divided into narrow sections. The position of different component sections was sequentially alternated. Despite the change in the plasma ring diameter or thickness, the area ratio of the vaporizable components remained unchanged due to sector design of the target. The effect of plasma on different materials was varied. That is why different materials were evaporated with various speeds at identical plasma parameters. To calculate the ratio of areas of the target components, it was necessary to determine the evaporation coefficient of each component.

So initially, the target for each component was prepared. In addition, the deposited film mass was determined sufficiently accurately by weighing on precision balance of the substrate made for each component of the target separately. It was important that all working parameters of the device were repeated punctually during each film deposition process including the distance from the target to the substrate which must have been selected taking into account the strong heating of the target by infrared radiation from the plasma torus. The substrate was weighed immediately after film deposition and cooling in vacuum. This was necessary due to the possible subsequent oxidation of the deposited components.

The following expression was used to calculate the ratio of the number of deposited atoms of components $K_{1}$ (for a two-component system): 


$$
K_{1}=m_{\mathrm{A}} M_{\mathrm{B}} /\left(M_{\mathrm{A}} m_{\mathrm{B}}\right)=\mathrm{A}_{1} / \mathrm{B}_{1},
$$

where $m_{\mathrm{A}}, M_{\mathrm{A}}, m_{\mathrm{B}}, M_{\mathrm{B}}$ are the masses and atomic masses of target components $\mathrm{A}$ and $\mathrm{B}$, respectively.

The ratio of the component areas can be calculated by the expression:

$$
K_{2}=K_{0} / K_{1}=B_{1} A_{0} /\left(A_{1} B_{0}\right),
$$

where $K_{0}=A_{0} / B_{0}$ is the required ratio of components (for example, 1/5).

In addition, $K_{2}$ was the ratio of the sector angles. Then, the angle of $\mathrm{B}$ sector (in degrees) in the full target circle was $B^{\circ}=360^{\circ} /\left(1+K_{2}\right)$ and, respectively, the angle of $\mathrm{A}$ sector was $A^{\circ}=360^{\circ}-\mathrm{B}^{\circ}$. To obtain a stoichiometric film on the substrate surface, 12 or more (no protrusions) flat sectors had to be placed on the target circle. These were the sectors with angles $A^{\circ} / 6, B^{\circ} / 6$.

When depositing a multicomponent alloy, it is necessary to set the sputtering parameters that were used earlier in determining the sputtering coefficients $K_{1}$. W and $\mathrm{B}$ atoms sputtered from the composite target surface had ultra-high velocity of thermal relaxation on the substrate $\left(10^{12}-10^{13} \mathrm{~K} / \mathrm{s}\right)$ and various spread in directions and speeds. These effects explained the homogeneity of the film composition. Using preliminary experimental results one can determine with sufficient accuracy (up to within 3 at. \%) the alloy composition in the film. The films $\mathrm{WB}_{5}$ were deposited in argon atmosphere ( $P=1 \mathrm{~Pa}$ chamber pressure) under the deposition parameters such as the target-substrate distance of $45 \mathrm{~mm}$, automatic bias voltage of $800 \mathrm{~V}, \mathrm{RF}$ power of $60 \mathrm{~W} / \mathrm{cm}^{2}$ and deposition rate of $30 \mathrm{~nm} / \mathrm{min}$.

We performed the deposition under equal conditions simultaneously onto the Sitall-substratums (ST-32-1) and the freshly cleaved crystals of sodium chloride. The alloy films deposited onto $\mathrm{NaCl}$ were separated by dissolving the salt in distilled water and used for studying the structure and composition by X-ray diffraction and electron microscopy techniques. The electrical properties were studied using the films deposited onto Sitallsubstratum. The sheet resistance $\left(R_{\mathrm{sh}}, \Omega / \square\right)$ was measured by the four-point probe technique with continuous heating of the film in vacuum $\left(10^{-2} \mathrm{~Pa}\right)$. The structure of the initial and annealed films was studied by the Xray diffraction patterns obtained with X-ray Debye camera and filtered CoKá radiation. In the $\mathrm{WB}_{5}$ composition, we succeeded in suppressing the process of formation of $\mathrm{W}$ - and B-crystalline phases and in fixing an amorphous solid state. This result was evidenced by the presence of only diffuse halo in the X-ray diffraction pattern at the angle of $24.2^{\circ}$. We have calculated the sizes of effective coherent scattering regions $(L)$ of this amorphous phase by the Selyakov-Scherrer formula $L=0.94 \lambda /(\beta \cos \Theta)$, where $\beta$ is the integral width of diffraction line; $\Theta$ is the Bragg reflection angle; $\lambda$ is the wavelength of $\mathrm{X}$-radiation. They were equal to $L=0.96 \mathrm{~nm}$ (value $L$ for pure amorphous $\mathrm{W}$ was equal to $1.9 \mathrm{~nm}$ at a diffraction angle of $22.9^{\circ}$ ). The shortest interatomic distances $R$ by the Ehrenfest relation for amorphous $\mathrm{WB}_{5}(R=\lambda /(E \sin \Theta)$, where the structure dependent constant $E=1.625 ; \lambda$ is the X-ray radiation wavelength; $\Theta$ is the position of the first maximum) were $0.267 \mathrm{~nm}$ (for amorphous $\mathrm{W} R=0.283 \mathrm{~nm}$ ) due to the compressive influence of B atoms in the amorphous state. Crystallization of the amorphous phase passed by the mechanism of original crystallization with the appearance of intermediate nanocrystalline phase (NCP) $(L=3.9 \mathrm{~nm})$, Fig. 3 .

The size $R$ of NCP was $0.314 \mathrm{~nm}$. It was experimentally determined that $\mathrm{W}$ possessed three modifications at various conditions - amorphous and two crystalline modifications such as ordinary body centered cubic (BCC) $(a=0.3165 \mathrm{~nm})$ and metastable face centered cubic (FCC) structures. The last structure was formed during vapor deposition on substrate above $370 \mathrm{~K}$ and at a thickness less than $2.5 \mathrm{~nm}$ and had the lattice parameter $a=0.4131 \mathrm{~nm}$. The period of metastable NCP ( $a=0.4175 \mathrm{~nm}$ ) from our data was determined by the (111) line for the FCC-structure after the initial stage of crystallization of amorphous phase.

From this, we considered that the process of crystallization of amorphous phase in $\mathrm{WB}_{5}$ alloy was passing through the stage of formation and disintegration of metastable NCP on the base of FCC-structure according to the thermodynamic rule of Ostwald stages. The position of the first metastable FCC-line of NCP, in our opinion, may testify about the same nearest coordination of $\mathrm{W}$ atoms in the amorphous state in films. The heat treated amorphous $\mathrm{WB}_{5}$ films above $1073 \mathrm{~K}$ showed the equilibrium structure with a period of $\mathrm{W}$ $(a=0.3176 \mathrm{~nm})+$ B-phase + complex oxide (WBO) with interplanar distances $0.2544,0.2087,0.1793,0.1597$, $0.1381,0.1370,0.1232,0.1211,0.1074,0.1011$, and $0.0991 \mathrm{~nm}$. The dot-characteristic of X-ray diffraction lines of this oxide indicated a significant oxidation of surface and a relatively large size of the oxide of $\mathrm{WB}_{5}$ films at this temperature. From here, it may be suggested that crystallization of amorphous $\mathrm{WB}_{5}$ films passed by original formation and following decomposition of NCP.

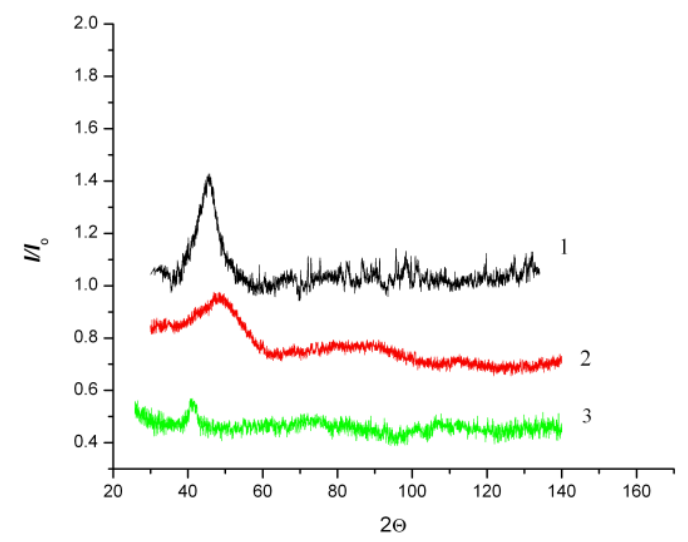

Fig. 3 - XRD patterns (intensities' angular relations) of: 1) assputtered W film ( $L \sim 1.9 \mathrm{~nm}) ; 2$ ) as-sputtered W-B film $(L \sim 0.9 \mathrm{~nm})$; 3$)$ W-B film after annealing at $973 \mathrm{~K}(L \sim 3.9 \mathrm{~nm})$

\section{RESULTS AND DISCUSSION}

\subsection{Electrical Properties of $\mathrm{WB}_{5}$ Films}

In parallel with the X-ray diffraction analysis, the phase transformations in $\mathrm{WB}_{5}$ films were traced by constructing the plots of relative $\left(R_{\mathrm{T}} / R_{300}\right)$ electrical resistivity versus temperature (polytherms) with con- 
tinuous heating of the films in vacuum with measuring the temperature coefficient of resistivity (TCR) and by studying the prolonged thermal stability of the films. The TCR in the amorphous film went into the region of negative values $\left(-1.1 \cdot 10^{-3} \mathrm{~K}^{-1}\right)$, which indicated the similarity of the electrical properties of $\mathrm{WB}_{5}$ films with the properties of semiconductor materials. In addition, the temperature behavior of relative resistance was typical of amorphous semiconductors (Fig. 4).

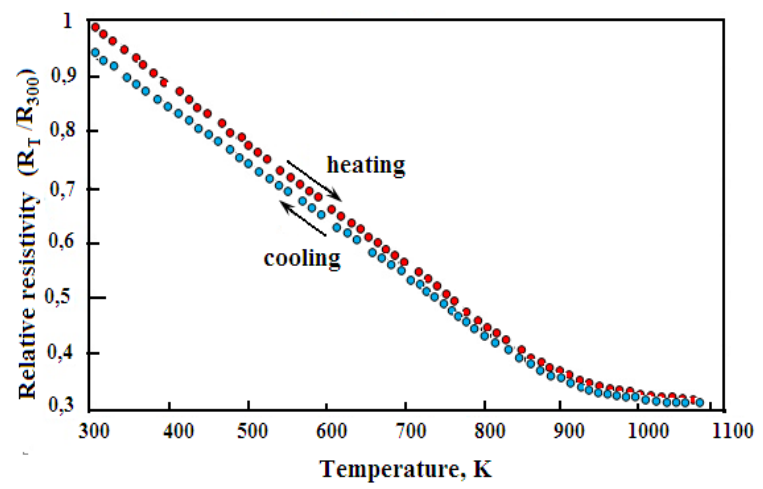

Fig. 4-Temperature variation of relative resistivity of amorphous $\mathrm{WB}_{5}$ films

We assume that the electrical properties of the obtained films are determined by the peculiarities of the properties of amorphous boron which prevails in the composition of $\mathrm{WB}_{5}$ films. It is known that amorphous boron films contain the nanocrystalline inclusions distributed in an amorphous matrix [20]. The presence of nanoinclusions leads to the decrease in local stresses and as a result to the reduction of the defect density in this matrix. Therefore, the fluctuations of the valence band edge decrease. Accordingly, the decrease in the activation energy and increase in the carrier mobility are observed [20]. It is possibly, the similar nanoinclusions are formed in the amorphous $\mathrm{WB}_{5}$ films. Within the framework of this idea, most likely, the existence of boron nanoinclusions determines the peculiarities of the charge transport mechanism in $\mathrm{WB}_{5}$ films.

The polytherm exhibits no signs of structural transformations up to a temperature of $873 \mathrm{~K}$, while the TCR varies reversibly and amounts to about $-1.1 \cdot 10^{-3} \mathrm{~K}^{-1}$.

The amorphous to nanocrystalline phase transformation in $\mathrm{WB}_{5}$ films is studied at temperatures from $873 \mathrm{~K}$ to $1073 \mathrm{~K}$. Fig. 4 shows the slight bend in the $R_{\mathrm{T}} / R_{300}=f(T)$ dependence near $\sim 880 \mathrm{~K}$. However, visual alterations on the diffraction patterns are not discovered in this temperature range. This indicates the absence of structural transformations and may be the result of conductivity mechanism change. From polytherms, it follows that relative electrical resistance in this interval becomes slightly less and at $300 \mathrm{~K}$ after cooling down it is approximately equal to 0.95 relative to the primary 1.0. Some reduction in resistance during cooling can be associated with partial ordering of the $\mathrm{WB}_{5}$ amorphous structure that leads to the increase in the electron free path. Above $1073 \mathrm{~K}$, experiments are not performed due to limited technical capabilities. As a result, we may say that thermal stability of the amorphous state of $\mathrm{WB}_{5}$ films is very high in comparison with amorphous specimens of other systems.

\subsection{Mechanical Properties of WB5 Films}

$\mathrm{WB}_{5}$ films with a thickness of 650 and $830 \mathrm{~nm}$ were sputtered on a cold glass substrate. Microhardness of thespecimens was measured by PMT-3 microhardness meter at a load of $20 \mathrm{~g}$. Microhardness of the films was $6 \mathrm{GPa}$ and $7 \mathrm{GPa}$, respectively. For comparison, the microhardness of sputtered $\mathrm{W}$-foils was equal to 4.5 $\mathrm{GPa}$ (the $\mathrm{W}$ table value was $4.7 \mathrm{GPa}$ ).

So it may be certified that the sputtered amorphous $\mathrm{WB}_{5}$ films have a microhardness 1.5 times higher than that of $\mathrm{W}$-foils. From this it follows that microhardness of the amorphous state in $\mathrm{WB}_{5}$ films does not allow to receive the superhard properties in theoretical values of crystalline compound $\mathrm{WB}_{5}$ [18] due to peculiarity in arrangement of boron atoms in the W-lattice. Thus, the highest degree of disorder in the mutual disposition of $\mathrm{W}$ and $\mathrm{B}$ atoms in compound $\mathrm{WB}_{5}$ limits the possibility of higher values of mechanical properties.

\section{CONCLUSIONS}

1. It is established that ion-plasma $\mathrm{RF}$ magnetron sputtering technique $(13.56 \mathrm{MHz})$ with the use of a composite target allows to obtain an amorphous state in high boron phase $\mathrm{WB}_{5}$.

2 . The thermal stability $(873 \mathrm{~K})$ of the deposited amorphous $\mathrm{WB}_{5}$ phase is at the level of highest thermostable amorphous alloys.

3 . It is fixed the formation of a metastable nanocrystalline FCC-phase $(a=0.4175 \mathrm{~nm})$ on W base in the process of decomposition of amorphous phase $\mathrm{WB}_{5}$.

4. The microhardness of the amorphous state in $\mathrm{WB}_{5}$ films due to the peculiarity of the arrangement of boron atoms in the W-lattice does not allow to obtain superhard properties in the theoretical values of crystalline compound $\mathrm{WB}_{5}$.

\section{REFERENCES}

1. I.M. Spiridonova, Visnyk Dnipropetrovs'kogo universitetu. Fizyka. Radioelektronika 16 Iss. 15/2, 97 (2008) [In Ukrainian].

2. E.S. Skorbyaschensky, S.N. Antropov, Visnyk Dnipropetrovs'kogo universitetu. Fizyka. Radioelektronika 25 Issue 24,42 (2017).

3. Z.A. Matysina, D.V. Schur, S.N. Antropov, S.Yu. Zaginaichenko, Metallofiz. Nov. Tekhnol. 29 No 7, 909 (2007).

4. A.S. Prokhoda, A.M Ovrutsky, S.S. Antropov, A.A. Mukhin, Visnyk Dnipropetrovs'kogo universitetu. Fizyka. Radioelektronika 4 Iss. 14, No 12/1, 90 (2007) [in Russian].

5. V.F. Bashev, S.I. Ryabtsev, O.I. Kushnerev, N.A. Kutseva, S.N. Antropov, East Eur. J. Phys. 3, 81 (2020).

6. E.S. Skorbyaschensky, V.F. Bashev, A.N. Polishko, S.N. Antropov, J. Phys. Electron. 27 No 2, 51 (2019).

7. Q. Gu, G Krauss, W. Steurer, Adv. Mater. 20, 3620 (2008).

8. ASM Handbook 3: Alloy Phase Diagrams (Ed. H.Okamoto, M.E. Schlesinger, E.M. Mueller) (ASM Intern.: 2016).

9. W.D. Callister Jr., D.G. Rethwisch, Materials Science and Engineering: An Introduction, 10th Edition. ISBN: 978-1119-40549 (EPUB: 2018).

10. Y. Wang, J. Lv, L. Zhu, Y. Ma, Phys Rev B 82, 094116, (2010). 
11. X.Y. Cheng, X.Q. Chen, D.Z. Li, Y.Y. Li, Acta Cryst. C70, 85 (2014).

12. A. Jain, Y. Shin, K.A. Persson, Nat. Rev. Mater. 1, 15004 (2016).

13. Q. Li, D. Zhou, W. Zheng, Y. Ma C. Chen, Phys. Rev. Lett. 110, 136403 (2013).

14. A.R. Oganov, A.O. Lyakhov, M.Valle, Acc. Chem. Res. 44 No 3, 227 (2011).

15. R. Mohammadi, A.T. Lech, M. Xie, B.E. Weaver, M.T. Yeung, S.H. Tolbert, R.B. Kaner, P. Natl. Acad. Sci. USA 108 No 27 , 10958 (2011)
16. A.T. Lech, C.L. Turner, R. Mohammadi, S.H. Tolbert, R.B. Kaner, P. Natl. Acad. Sci. USA 112 No 11, 3223 (2015).

17. G. Akopov, I. Roh, Z.C. Sobell, M.T. Yeung, L. Pangilinan, C.L. Turner, R.B. Kaner, J. Am. Chem. Soc. 139 No 47, 17120 (2017).

18. A.G. Kvashnin, H.A. Zakaryan, C. Zhao, Y. Duan, Y. Kvashnina, C. Xie, H. Dong, A.R. Oganov, J. Phys. Chem. Lett. 9, 3470 (2018).

19. Handbook of Materials Modeling (Ed. W. Andreoni, S. Yip) (Cham: Springer: 2020)

20. O.A. Golikova, Semiconductors+ 34, 363 (2000).

\title{
Метастабільні стани і фізичні властивості збагачених бором W-B плівок
}

\author{
В.Ф. Башев, С.І. Рябцев, Т.В. Крузіна, С.О. Попов, С.С. Скорбященський, Ю.М. Потапович, \\ C.M. Антропов
}

Кафбедра експерилентальної фізики, Дніпровський національний університет ілені Олеся Гончара, 72 пр. Гагаріна, 49010 Дніпро, Україна

\begin{abstract}
Представлені експериментальні дані по іонно-плазмовому (13.56 МГц) магнетронному напиленню складових мішеней системи W-B. Застосування зазначеного методу дозволяе отримувати напилен сплави в усьому концентраційному інтервалі їх складів. Напилені плівки ілюструють виникнення аморфного твердого стану. Розкладання аморфного стану супроводжуеться виділенням проміжної метастабільної, нанокристалічної W-фази з гранецентрованою кубічною структурою. За допомогою магнетронного напилення ми отримали аморфний стан в чистих $\mathrm{W}$-плівках при кімнатній температурі. Досліджено метастабільні стани в W-B плівках, їх термічна стабільність, електричні і механічні властивості. В роботі показано, що аморфний стан в сплаві $\mathrm{WB}_{5}$ характеризуеться аномально високою температурною стійкістю і мікротвердістю. Метод іонно-плазмового розпилення продемонстрував свою ефективність в разі плівок вольфраму, показавши можливість отримання в них метастабільних фоз. Разом з тим, отримані значення мікротвердості в аморфному сплаві виявилися нижчими передбачених максимальних теоретичних значень внаслідок особливостей розташування атомів в сплаві.
\end{abstract}

Ключові слова: Іонно-плазмове магнетронне розпилення, Аморфний стан, Метастабільні стани, W-B плівки, Температурна стабільність, Мікротвердість. 